STUDIA HISTORICA GEDANENSIA

TOM XII (2021)

\author{
Julia Możdżeń \\ (Uniwersytet Gdański) \\ https://orcid.org/0000-0003-4932-5546
}

\title{
Kiła, ospa, angielskie poty. Zapomniane epidemie w Prusach i na Pomorzu w latach 1527 i 1529
}

Słowa kluczowe: Simon Grunau, angielskie poty, syfilis, ospa, epidemie, Prusy, Pomorze, Gdańsk, Królewiec, Toruń, Szczecin

Keywords: Simon Grunau, English sweats, syphilis, smallpox, diseases, Prussia, Pomerania, Gdansk, Krolewiec, Torun, Szczecin

W historii epidemii występujących na ziemiach polskich i pruskich w latach 1527 i 1529 zaistniały dwie fale mniej znanych, dość enigmatycznych plag, które nawiedziły w krótkim czasie wybrane regiony, miasta albo też wystąpiły raz i nigdy więcej ich nie odnotowano. Były to plagi nowe, o których wcześniej nie słyszano bądź nie pamiętano podobnych. Analogicznie jak dziś dla nas epidemia SARS-CoV-2, wśród szesnastowiecznych autorów owe nowe plagi wywoływały skrajne emocje od przerażenia i nastrojów millenarystycznych po zwątpienie w rzeczywiste zagrożenie, jakie stanowiły. Jak pokazuje analiza źródeł narracyjnych, emocjonalne reakcje naszych przodków $\mathrm{i}$ ich zachowania związane z zagrożeniem nie odbiegały od obserwowanych przez nas na co dzień. Można powiedzieć, że w tym sensie są zapisem typowo ludzkich reakcji.

Artykuł ma na celu zebranie i przeanalizowanie narracyjnego materiału spisanego w pruskich i pomorskich miastach w trakcie trwania epidemii z lat 1527 i 1529 (relacje kronikarskie i listy) oraz w krótkim czasie po nich. Dotąd takich analiz dla tego regionu nie przeprowadzono. Interesować mnie będą nie tylko objawy choroby i liczba ofiar, ale przede wszystkim reakcje władz miejskich i samych mieszczan na pojawienie się choroby, zalecane środki zaradcze oraz interpretacje sposobów rozprzestrzeniania się. W tym sensie artykuł ten wpisuje się w badania nad dziejami wyobrażeń. Punktem wyjścia w analizie są bliżej nieznane literaturze obszerne relacje dominikanina Simona Grunaua o epidemiach z lat 1527 i 1529. 
Należy je traktować jako relacje naocznego świadka ${ }^{1}$. Jego obserwacje są nader szczegółowe i zasługują na bliższą analizę ${ }^{2}$. Nie można wykluczyć, że kronikarz ten sam stał się ofiarą jednej z tych plag $^{3}$, gdyż ostatnie passusy swojej imponującej rozmiarami Kroniki Pruskiej spisywał w grudniu 1529 r. lub na początku stycznia $1530 \mathrm{r}^{4}$, mając już gorączkę . Dotąd źródło to w historii epidemiologii było pomijane. Pragnąc ocenić wiarygodność relacji Grunaua ${ }^{6}$, zebrano i przeanalizowano inne, zbieżne chronologicznie przekazy epistolarne i kronikarskie, które zaowocowały obszernym aneksem źródłowym ${ }^{7}$.

Oprócz teologiczne objaśnienia przyczyn występowania owych epidemii, kronikarz ten opisuje dość szczegółowo objawy, sposoby leczenia i podejmowane środki zaradcze. Jako pierwszą przywołuje jesienią 1527 r. epidemię tzw. choroby francuskiej, tj. syfilisu. Znana była ona w Prusach jako choroba zakaźna, lecz jak pisze Grunau, nigdy wcześniej nie przybrała tak agresywnej postaci ${ }^{8}$. Przypadłość ta w zakaźnej odmianie pojawiła się po raz pierwszy około $1495 \mathrm{r}$. wśród wojsk francuskich wkraczających w Neapolu. Stąd w tej części kontynentu nazywano ją chorobą francuską lub neapolską . Grunau określa ją także mianem "francy”. Morbus gallicus, po polsku zwana dawniej "przymiotem”, uznawana była na początku XVI w. za względnie nową chorobę, która od lat dziewięćdziesiątych XV w. stale pojawiała się w całej Europie. Początkowo widziano w niej odmianę trądu ze względu na podobne objawy obserwowane w jej stadium zaawansowanym. Budziła też nie mniejsze niż trąd przerażenie. Analogicznie jak

1 Była to tzw. trzecia redakcja kroniki, którą opracował Grunau, pisana na jego własne potrzeby. Szerzej o datowaniu poszczególnych partii kroniki i ich przeznaczeniu zob. Sławomir Zonenberg, Kronika Simona Grunaua (Bydgoszcz: Wydawnictwo Uniwersytetu Kazimierza Wielkiego, 2009), 42-45.

2 Autorka krótko wspomniała o nich w pracy, Julia Możdżeń, Przedstawianie świata przez dziejopisarzy gdańskich na przełomie XV i XVI wieku (Toruń: Wydawnictwo Naukowe UMK, 2016), 241-245.

Zonenberg, Kronika, 115.

4 Ibidem, 45.

5 Ibidem, 115.

6 Złożony problem wiarygodności kroniki Grunaua charakteryzuje S. Zonenberg (Kronika, 76-107), ostatnio także szerzej: idem, „Kwestia wiarygodności kroniki Simona Grunaua”, w Księga pamiątkowa prof. Tomasza Nowakowskiego, red. D. Karczewski, D. Dąbrowski (Bydgoszcz: Wydawnictwo Uniwersytetu Kazimierza Wielkiego, 2021), 1-27, [w druku].

7 W aneksie zamieszczono wypisy ze źródeł rękopiśmiennych oraz wydanych w XIX w., spisanych w momencie trwania epidemii na obszarze Pomorza i Prus, a najpóźniej w połowie XVI w. Wyjątkiem jest tzw. Kronika Pelplińska z ok. 1588 r., Archiwum Diecezjalne w Pelplinie, Chronica Monasterii Sacri Ordinis Cisterciensium Pelplin, vol. 1, codex 421 (622) (dalej: Kronika Pelplińska); zob. załączniki źródłowe.

8 Simon Grunau's Preussische Chronik, hrsg. v. Paul Wagner, Bd. 3 (Leipzig: Duncker \& Humblot, 1896), 228 (dalej: Grunau).

9 Szeroko o historii kiły zob. Claude Quétel, Niemoc $z$ Neapolu czyli historia syfilisu (Wrocław: Zakład Narodowy im. Ossolińskich, 1991), 14-45; Stephen V. Black, „Syfilis: morbus gallicus”, w Wielkie epidemie w dziejach ludzkości, red. Kenneth F. Kiple (Warszawa: Oficyna Wydawnicza Atena, 2002), 163-164. 
trędowatych traktowano chorych na syfilis w Paryżu, choć bardzo szybko egzekwowanie wyroków banicji stało się niemożliwe ze względu na powszechność choroby $^{10}$. Jej pojawienie się w Europie szybko skojarzono z odkryciem Nowego Świata ${ }^{11}$. Ślady zmian kostnych wywoływanych przez kiłę znaleziono w szczątkach dawnych mieszkańców kontynentu amerykańskiego liczących 8 tys. lat, a także dowiedziono, że była ona aktywna w czasach Krzysztofa Kolumba ${ }^{12}$. W Polsce pierwszy przypadek zanotował Jan Długosz pod 1495 r. u kobiety, która wróciła z pielgrzymki do Rzymu ${ }^{13}$. Choroba ta ma wiele odmian, niektóre bardziej zjadliwe formy współcześnie już nie występują. Historycy medycyny nadal mają problem z identyfikacją różnorodnych opisów zmian skórnych opisywanych przez kronikarzy $^{14}$. Oddajmy jednak głos gdańskiemu kronikarzowi.

Epidemia syfilisu w Prusach była zdaniem kronikarza bardziej zaraźliwa niż dotychczas i bardziej bolesna oraz odporna na zwyczajowe zabiegi lekarzy „francuskich”. Dotychczas znane leki miały pogarszać stan pacjentów. Leczenie polegało na wcieraniu tzw. szaruchy, później podawano także odwary z rośliny zwanej gwajakiem (nalewka gwajakowa). Inna metoda polegała na wkładaniu chorych do dobrze ogrzanego pieca, aby się wypocili po nacieraniu rtęcią. Kuracja trwała zwykle trzy miesiące, a wielu cierpiących umierało przed jej zakończeniem ${ }^{15}$. Powyższe stwierdzenie Grunaua świadczy o tym, że wiedza o objawach i leczeniu syfilisu była powszechna. Występowanie kiły na terenie Pomorza na przełomie XV i XVI w. potwierdza też zachowany materiał archeologiczny ${ }^{16}$.

W ciągu całego dwudziestolecia XVI w. ukazały się w Europie liczne druki poświęcone tej chorobie i metodom jej leczenia ${ }^{17}$. Medycy z końca lat dwudziestych XVI w. relacjonowali słabnącą zjadliwość choroby. Ulrich von Hutten (1488-1523) i Johannes Benedictus (1483-1564) wskazywali, że słabnięcie epidemii

10 Quétel, Niemoc z Neapolu, 35.

11 Ibidem, 37 i n.

12 Bruce Rothschild, „History of Syphilis”, Clinical Infectious Diseases 40, no. 10 (May 2005): 1460-1461, http://www.jstor.com/stable/4484215, dostęp: 17 XI 2021 r. Niektórzy badacze sugerują, że kiła występowała w Europie już wcześniej, lecz miała znacznie łagodniejszy przebieg. Brak potwierdzenia tej teorii w materiale archeologicznym. Szerzej zob. Małgorzata Grupa, Tomasz Kozłowski, „Infekcje swoiste w populacjach historycznych z obszaru Pomorza Nadwiślańskiego i Kujaw w świetle źródeł antropologicznych i archeologicznych na przestrzeni ostatniego tysiąclecia”, w Epidemie $w$ dziejach Europy. Konsekwencje społeczne, gospodarcze i kulturowe, red. Krzysztof Polek, Łukasz Tomasz Sroka (Kraków: Wydawnictwo Naukowe Uniwersytetu Pedagogicznego, 2016), 113, tam dalsza literatura.

13 Aleksandra Gawlikowska-Sroka, Edyta Dzięciołowska-Baran, „Kiła dawniej i dzis”, Annales Academiae Medicae Stetinensis. Roczniki Pomorskiej Akademii Medycznej w Szczecinie 59, no. 2 (2013): 163.

14 Zob. zwłaszcza przedstawienia malarskie na ołtarzu Wita Stwosza, Franciszek Walter, Wit Stwosz rzeźbiarz chorób skórnych. Szczegóty dermatologiczne ołtarza marjackiego (Kraków: Księgarnia Gebethnera i Wolffa, 1933), 17-18.

15 Quétel, Niemoc z Neapolu, 76-79.

16 Grupa, Kozłowski, Infekcje swoiste, 115.

17 Ich treść porównuje i omawia: Quétel, Niemoc z Neapolu, 36-41. 
zaczęło być odczuwalne około $1508 \mathrm{r}^{18}$ Kolejne osłabienie stopnia zakaźności syfilisu odnotowują francuscy kronikarze na przełomie lat dwudziestych i trzydziestych XVI w. ${ }^{19}$, co mogło być specyfiką regionalną.

Odmiana syfilisu w Prusach objawiała się wykwitami skórnymi w kształcie „listków” („blatter”) i owrzodzeniem ${ }^{20}$, z wyglądu owe wykwity przypominały ospę prawdziwą i początkowo także stosowano wobec nich tę samą nazwę variola ${ }^{21}$. Już w 1496 r. powstał pierwszy traktat opisujący rozwój syfilisu prowadzającego do ropiejących wrzodów na skórze, atakującego kości i mózg.

Grunau opisuje także przesądy związane z możliwościami zarażenia się. Mianowicie, wielu biedaków dotkniętych tą chorobą - mimo bolesnych dolegliwości musiało nadal zarabiać na chleb. Ich panowie zarażali się od nich, a doprowadzać do tego miało przerażenie wywołane ich wyglądem. Powstało stąd przekonanie, pisał Grunau, że chorobą można zarazić się w wyniku szoku wywołanego widokiem chorego na syfilis ${ }^{22}$. Analogiczne przekonanie podzielał Ulrich von Hutten (1488-1524), opisujący osobiste doświadczenia w walce $\mathrm{z}$ tą chorobą w dziele wydanym w 1519 r. ${ }^{23}$ Pisał on: „Wrzody i rany tworzyły się w kształcie i wielkości dębowych żołędzi, wydzielała się z nich zjadliwa ciecz rozprzestrzeniając taki smród, że ten, który go poczuł, był przekonany, iż już zaraził się tą chorobą" ${ }^{24}$.

Grunau był przekonany, że epidemia syfilisu dotykała także zwierzęta domowe $^{25}$. Czy jednak rzeczywiście było to to samo schorzenie? Zauważono bowiem - pisał - że choroba ta występowała powszechnie u zwierząt rzeźnych. Grunau podaje, że w 1527 r. po św. Michale, tj. po 30 września, w okresie corocznego uboju zwierząt rzeźnych - na bydle, osłach, świniach zauważono takie same charakterystyczne „listki” na skórze, jak u ludzi, co więcej, ślady po owrzodzeniu znajdywano także na mięsie ubitych sztuk. Rajcy miejscy (niestety nie wiemy, o które miasto chodziło) nakazali wyrzucić całe zarażone mięso, lecz jak pisze Grunau, wielu biedaków je znalazło i zjadło. Stało się jasne, że rzeźnicy przez cały rok sprzedawali mięso chorych zwierząt. Kronikarz sugeruje zatem, że choroba przenosić miała się ze zwierząt na ludzi. Dalej Grunau relacjonuje, że gdy chciano ukarać rzeźników zgodnie z wilkierzem za sprzedaż zepsutego mięsa tłumaczyli oni, że dotąd tego typu choroba była im nieznana. Odtąd niewiele

$\begin{array}{ll}18 & \text { Ibidem, 65. } \\ 19 & \text { Ibidem, 66. } \\ 20 & \text { Grunau, Bd. 3, } 272 . \\ 21 & \text { Szerzej zob. Quétel, Niemoc z Neapolu, } 37 . \\ 22 & \text { Grunau, Bd. 3, 228. } \\ 23 & \text { Ulrich von Hutten, De guaiaci medicina et morbo gallico (Mogvtiae: Schöffer, 1519). Dzieło }\end{array}$ to szybko przełożono na język niemiecki (Strasburg 1519) i francuski (Paryż ok. 1520). Zob. także Manfred Vasold, Pest, Not und schwere Plagen. Seuchen und Epidemien vom Mittelalter bis heute (Augsburg: Bechtermünz-Verlag, 1999), 113-114.

24 Cyt. za: Quétel, Niemoc z Neapolu, 40.

25 Grunau, Bd. 3, 229. 


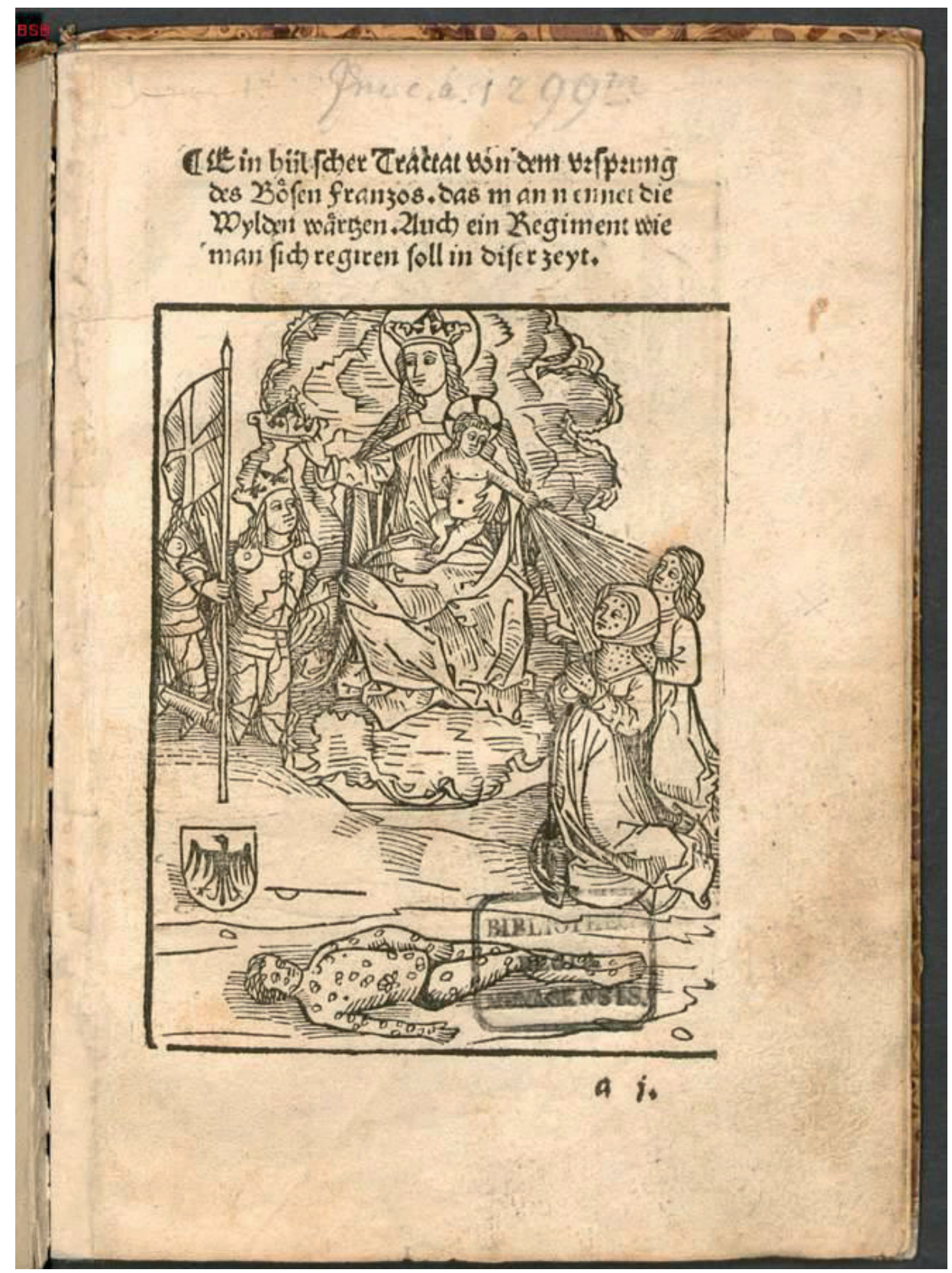

Il. 1. Karta tytułowa niemieckojęzycznego tłumaczenia traktatu o nowej chorobie francuskiej Josepha Grünpecka z 1496 r. Drzeworyt ukazuje chorych na syfilis, których ciała pokryte są wrzodami

Źródło: Bayerische Staatsbibliothek, sygn. 4 Inc.c.a. 1299 m, https://bildsuche.digitale-sammlungen. de/index.html? $\mathrm{c}=$ viewer\&l $=$ de\&bandnummer $=$ bsb00027711\&pimage $=00002 \& v=100 \&$ nav $=$, dostęp: 3 III $2021 \mathrm{r}$. 
mięsa sprzedawano, a kto je kupił, był odnotowany i obserwowany - twierdzi kronikarz. Choroba miała także zmieniać smak mleka - wielu sprowadzało w tym czasie wyroby serowarskie z Holandii i Szwecji. Dotknęła ona również ptactwo domowe - kury, gęsi i kaczki. Chore, oszalałe kury biegały dookoła bez ustanku, aż padały martwe. Ślady zakażenia znajdowano już u małych, dopiero co narodzonych prosią ${ }^{26}$. Warto dodać, że pomór świń w listopadzie $1527 \mathrm{r}$. odnotowuje też w swych listach Marcin Luter ${ }^{27}$.

Szczegóły opisu Grunaua pozwalają wskazać kilka jednostek chorobowych, które mogły zaatakować zwierzęta i ludzi jesienią 1527 r. Wszystkie objawy, a więc zmiany skórne o charakterystycznym kształcie, zmiany anatomopatologiczne, a także organoleptyczne mleka występowały w przypadku ospy (variola) ${ }^{28}$. Do połowy XIX w. spotykana była pospolicie, dotykała zarówno krowy, owce, kozy, jak i świnie. Nosicielami wirusa byli ludzie, zazwyczaj dojarze, przenoszący go na zwierzęta. Choroba ta nie przenosiła się drogą kropelkową ${ }^{29}$, co tłumaczyć może efekt nowości opisany przez Grunaua, gdyż wirus trudno się rozprzestrzeniał. Mleko zakażonych krów wydzielało nieprzyjemną woń, zmniejszała się też ich mleczność ${ }^{30}$. Opisane przez Grunaua objawy neurologiczne u ptactwa domowego spotyka się natomiast w przypadku ptasiej grypy, która także objawia się krwawymi plamami na tkankach ${ }^{31}$. Drobiazgowy opis epidemiczny pozostawiony przez kronikarza znajduje zatem potwierdzenie w rzeczywiście istniejących jednostkach chorobowych i jest o tyle cenny, że dotyczy także, rzadko uwzględnianych w takim stopniu, epidemii zwierząt.

Niedługo po zarządzeniu rady miasta mieszkańcom ziemi pruskiej zajrzał w oczy głód. Sytuacja żywieniowa już i tak była katastrofalna - relacjonuje Grunau - gdyż po obfitym obrodzeniu zbóż na polach latem przyszły ulewne deszcze i całe pola stanęły w wodzie. Głód dotknął robotników najemnych z Mazowsza, którzy przybyli jak co roku do Prus wraz z żonami i dziećmi, by dorobić przy zbiorach. Na ich nieszczęście w tym roku nie było czego zbierać, gdyż wszystko zgniło. A ponieważ do tego doszła jeszcze epidemia syfilisu, nie wpuszczano głodujących Mazowszan do miast, zamykano przed nimi domostwa. Gdy biedacy ci chcieli wrócić na Mazowsze, zamknięto przed nimi granice z obawy, że przeniosą zarazę. Biedni ludzie - pisze kronikarz - pozostali więc z rodzinami,

26 Grunau, Bd. 3, 229.

27 Vasold, Pest, Not, 119.

28 R. Bochdalek, „Ospa u krów na terenie woj. wrocławskiego w związku ze szczepieniami przeciwospowymi u ludzi”, Medycyna Weterynaryjna 20/3 (1964): 168.

29 Ibidem, 168.

$30 \quad$ Ibidem, 168.

31 Pod uwagę wziąć można także posocznicę krwotoczną bydła (pasterelozę), która występuje u prawie wszystkich gatunków zwierząt, pomór klasyczny świń lub różycę świń. Za identyfikację historyczno-weterynaryjną dziękuję Panu dr. n. wet. Jarosławowi Sobolewskiemu z Centrum Weterynarii Uniwersytetu Mikołaja Kopernika w Toruniu. 
koczując na polach, żywiąc się dzikimi jabłkami, gruszkami i orzechami, a jesienią umierali z głodu i zimna. Ciała leżały na polach, pod płotami, bezskutecznie oczekując na pochówek. Trupami zajęły się wreszcie dzikie psy i wilki. Wspomniane deszcze zniszczyły także drogi dojazdowe do miast, co wywołało problemy z dostarczeniem drewna na opał. Krowy głodowały, tak jak ludzie, z braku paszy. Jeśli konie wypuszczono do ogrodów, by się pożywiły, tam zżerały je wilki, ponieważ przestały bać się ludzi, a psy ich nie odganiały, ponieważ także były najedzone ludzką „padliną” ${ }^{32}$. Oto obraz rozpadu stosunków społecznych, które rozbijał strach przed pochodem śmierci. Wilki i zdziczałe psy, od wieków uosabiające dzikość i zagrożenia natury, zburzyły dominującą pozycję człowieka w przyrodzie i raz jeszcze odwróciły chwiejne proporcje w układzie sił między światem kultury a natury.

Zupełną nowością była epidemia tzw. angielskich potów ${ }^{33}$ w 1529 r., którą odnotowali kronikarze w Szczecinie, Gdańsku, Toruniu i Królewcu. Liczbę ofiar w Gdańsku szacuje się na 3-6 tys. ${ }^{34}$ Nazwa tej choroby zakaźnej pochodzi od miejsca jej pierwszego wystąpienia, tj. Anglii. Jej pierwsze uderzenie zarejestrowano w $1485 \mathrm{r}$. pod koniec Wojny Dwóch Róź ${ }^{35}$, gdy zdziesiątkowała ona żołnierzy walczących pod Bosworth 22 sierpnia 1485 r. ${ }^{36}$ Anglicy byli przekonani, że choroba atakuje tylko ich ${ }^{37}$. Kolejne uderzenie nastąpiło w latach 1507 (1508?) i 1516-1518 $8^{38}$, a najsilniejsze w 1528 r. - zaczęło się w maju w Londynie, gdzie zachorowało 40 tys. ludzi, z czego 2 tys. zmarło. Po ponad roku, w lipcu 1529 r., choroba przedostała się do Hamburga i rozprzestrzeniła po miastach hanzeatyckich - Lubece, Bremie, Szczecinie, a następnie we wrześniu dotarła do Gdańska, Torunia, Królewca i Inflant. Późnym latem i we wrześniu pojawiła się też w Bawarii i Szwabii - zajęła Augsburg, Norymbergę, Kempten, Landshut, Memmingen i Ulm. Następnie przez

32 Grunau, Bd. 3, 229.

33 Inne nazwy to „Englische Schweiß” lub „Sudor anglicus”, mniej znane to „Schweiß-Pest”, „Pestis britannica”, „Englisches Schweyßbad”, „Ephemera britannica”, Heinz Flamm, "Anno 1529 - der «Englische Schweiß» in Wien, die Türken um Wien”, Wiener Medizinische Wochenschrift 170/3 (2020): 59-70, https://www.ncbi.nlm.nih.gov/pmc/articles/PMC7088414/, dostęp: 23 VI $2020 \mathrm{r}$.

${ }^{34}$ Andrzej Karpiński, $W$ walce z niewidzialnym wrogiem. Epidemie chorób zakaźnych w Rzeczypospolitej w XVI-XVIII wieku i ich następstwa demograficzne, społeczno-ekonomiczne i polityczne (Warszawa: Wydawnictwo Neriton, Instytut Historii PAN, 2000), 332.

35 Erich Püschel, „Der Englische Schweiß des Jahres 1529 in Deutschland. Eine medizinhistorisch-differentialdiagnostische Betrachtung", Sudhoffs Archiv für Geschichte der Medizin und der Naturwissenschaften 42/2 (1958): 168.

36 Flamm, „Anno 1529”, 59 i n.

37 Szczegółowo na temat skutków demograficznych i śmiertelności pierwszej epidemii zob. R.S. Gottfried „Population, Plague, and the Sweating Sickness. Demographic Movements in Late Fifteenth-Century England”, Journal of British Studies 17/1 (1977): 12-37.

38 Ibidem, passim; Paul R. Hunter, „The English Sweating Sickness, with Particular Reference to the 1551 Outbreak in Chester Reviews of Infectious Diseases", Reviews of Infectious Diseases 13/2 (1991): 304. 
Getyngę i Marburg w Hesji ${ }^{39}$ przedostała się jesienią do Wiednia ${ }^{40}$. Równolegle rozprzestrzeniała się także w Szwecji, Holandii, Danii i Rosji ${ }^{41}$.

Thomas Kanztow, kronikarz i historyk zachodniopomorski, obliczył, że epidemia ta potrzebowała tylko dwóch tygodni, by z Hamburga dotrzeć do Szczecina pod koniec sierpnia 1529 r. ${ }^{42}$ Przyczyny choroby, jak pisze kronikarz, upatrywano w pogodzie. Szerzyła się ona od Zielonych Świąt (16 maja) do św. Jakuba (25 lipca) na całym terenie Zalewu Szczecińskiego. Ludziom nagle martwiały ręce i nogi, jak dwóm rybakom na Odrze, którzy „porażeni” chorobą, nagle padli bez sił na łodzi. Otulono ich ciepło, dano grzanego piwa z masłem, dużo też jedli, a po trzech-czterech dniach ozdrowieli. Zdaniem Kantzowa przyczyną choroby była zatruta woda, gdyż w okresie Wielkiego Postu do rzeki wpłynęło wiele morświnów (tj. delfinów). Sporo tych zwierząt znaleziono martwych ${ }^{43}$. Następnie miały miejsce anomalie pogodowe - upał trwał aż do święta narodzin św. Jana, a następnie deszczowe i zimne lato utrzymało się aż do św. Bartłomieja, po czym znów uderzył upał. Przyczyniło się to do ogromnego nieurodzaju i zdaniem kronikarza upał ów, który nastąpił po okresie wilgotnym i zimnym, „zrodził” właśnie chorobę angielskich potów ${ }^{44}$. Choroba ta $\mathrm{w}$ Szczecinie jako pierwszego miała uśmiercić książęcego kucharza, który wieczorem położył się zdrowy do łóżka, o północy miał zacząć się pocić, a o piątej rano już nie żył ${ }^{45}$. Następnego dnia choroba szerzyć się miała już na całym dworze książęcym i w mieście. Chorych zaszywano w pierzyny, by się wypocili - była to ich jedyna szansa na ozdrowienie. Kantzow wspomina panikę tak wielką, że wielu ludzi z przerażenia kładło się do łóżek i pociło. Lekarze rozpoznawali śmiertelną chorobę po nieprzyjemnym zapachu potu, który wydzielali. Największe poruszenie nastąpiło w mieście kolejnej nocy, kiedy to kapłani i służący biegali bez ustanku z pochodniami do chorych. Rankiem nie było ulicy, przy której by nie zmarły minimum dwie-trzy osoby. Po dziewięciu dniach epidemia

${ }^{39}$ O jej pojawieniu się w Marburgu pisał m.in. Marcin Luther 4 X 1529 r. w liście do księcia Albrechta von Brandenburga-Ansbacha, WA, nr 1476, 154: „Johann Brenz, Andreas Osiander, Doctor Stephan von Augspurg seind auch hier kommen. Sie seind hier toll worden mit Schweißschrecken, gestern haben sich bei funfzig geleget, deren seind eins oder zwei gestorben".

40 Vasold, Pest, Not, 120-121; Püschel, „Der Englische Schweiß”, 168.

41 Szerzej na temat postępów epidemii w Europie i liczby ofiar zob. Andrzej K. Kuropatnicki, „Poty angielskie (sudor anglicus) tajemniczą chorobą zakaźną XV- i XVI-wiecznej Anglii”, w Epidemie $w$ dziejach, 145-151. Zob. także Kenneth F. Kiple, „Poty: angielska tajemnica”, w Wielkie epidemie $w$ dziejach ludzkości, red. idem (Poznań: Oficyna Wydawnicza Atena, 2002), 228.

42 Christian Gottfried Gruner, Scriptores de sudore Anglico superstites, ed. Heinrich Haeser (Jena: F. Maukius, 1847), 441.

43 Thomas Kantzow, Pomerania. Kronika pomorska z XVI wieku, tłum. Krzysztof Gołda, oprac. Tadeusz Białecki, Krzysztof Gołda, Edward Rymar (Szczecin: Uniwersytet Szczeciński: Archiwum Państwowe, 2005), 171; Des Thomas Kantzow Chronik von Pommern in hochdeutscher Mundart. Letzte Bearbeitung, hrsg. v. Georg Gaebel (Stettin: Paul Niekammer, 1897), 400 (dalej: Gaebel).

44 Kantzow, Pomerania, 172; Gaebel, 400.

45 Kantzow, Pomerania, 172; Gruner, Scriptores de sudore, 442; Gaebel, 400. 
w Szczecinie ustała, zabierając ze sobą kilka tysięcy ofiar. Ci, którzy przeżyli noc, byli wycierani ręcznikami do sucha i sadzani przy ogniu, należało przy tym szczególnie unikać przeciągu, następnie karmiono ich zupą jajeczną. Po ośmiu dniach chorzy dochodzili do siebie, ale bywali i tacy, którzy wymagali dłuższej rekonwalescencji ${ }^{46}$.

Pojawienie się epidemii angielskich potów na kontynencie europejskim w $1529 \mathrm{r}$. wywołało lawinę publikacji, drukowanych głównie przez lekarzy i aptekarzy z różnych krajów, opisujących gwałtowny przebieg tej choroby i stosowane przez siebie metody leczenia ${ }^{47}$. Choroba ta znana jest dziś wyłącznie z tychże opisów. Historycy medycyny już od XIX w. próbowali zidentyfikować jej podłoże biologiczne, lecz bez większych sukcesów, gdyż materiał biologiczny do analiz nie zachował się. W starszej literaturze znaleźć można pogląd, że mogła być to odmiana gorączki prosówkowej, ostrej grypy żołądkowej, co obecnie jest negowane ${ }^{48}$. Objawy kliniczne opisywane przez szesnastowiecznych wiedeńskich lekarzy i aptekarzy na podstawie prowadzonych przez nich badań i obserwacji w 1529 r. dają nam następujący obraz chorobowy: bóle i zawroty głowy, wymioty, dreszcze lub gorączka, ból serca z tachykardią, ból gardła i bóle całego ciała (zwłaszcza dłoni, nadgarstków i stóp). Mogły pojawić się krwawienia z nosa. Pacjenci stawali się melancholijni, cierpieli z powodu wielkiego strachu i majaczenia. Pragnęli zimnego powietrza, rozwijało się u nich silne uzależnienie od snu. Siła pacjenta spadała, a ciało obficie się pociło. Pot bardzo śmierdział (jak zgniłe jajka), był żółtawy i tak lepki, że można go wyciągnąć między palce. Przeważnie ciemny mocz był wytwarzany tylko w niewielkich ilościach, więc nie był wystarczający do postawienia diagnozy ${ }^{49}$. Choroba właściwie trwała 24 godziny, kto ją przetrwał, mógł uważać się za zdrowego. Chorego należało za wszelką cenę utrzymywać w przytomności, powinien pocić się i nie dopuszczać świeżego powietrza ${ }^{50}$. Dziś możliwe jest tylko porównywanie opisanych objawów względem obecnie występujących jednostek chorobowych. Pochodzące z 2020 r. analizy zespołu Williama P. Cheshire’a, Jaya A. van Gerpena i Jamesa J. Sejvara wskazują na wirusowe podłoże schorzenia atakującego układ nerwowy w rejonie podwzgórza i rdzenia kręgowego. Choć jednoznaczna identyfikacja typu wirusa nadal badaczom umyka, najczęściej winowajcy szuka się

46 Kantzow, Pomerania, 172; Gruner, Scriptores de sudore, 442; Gaebel, 401.

47 Tytuły te identyfikowalne są w VD16 (Verzeichnis der im deutschen Sprachbereich erschienenen Drucke des 16. Jahrhunderts), wersja on-line: VD16C5099; VD16F 814; VD16 H 1711;VD16 H5912; VD16H 5916; VD16 H 5919; VD16 H 5922; VD16 K 598; VD16 M 4441; VD16 R 598; VD16 T 2016; VD16 T 2020; VD16 V 2341; VD16 W 3065; VD16 ZV 3872; VD16 ZV 7614; VD16 ZV 7615; VD16 ZV 16872; https://www.bsb-muenchen.de/sammlungen/historische-drucke/recherche/vd-16/ dostęp: $17 \mathrm{XI}$ $2020 \mathrm{r}$.

48 Vasold, Pest, Not, 121, tam dalsze cytowania. Zob. także Kuropatnicki, „Poty angielskie”, $151-154$.

49 Flamm, „Anno 1529”; Püschel, „Der Englische Schweiß”, 169.

50 Grunau, Bd. 3, 273. 
w grupie hantawirusów, przenoszonych przez gryzonie ${ }^{51}$. Heinz Flamm z Instytutu Higieny Uniwersytetu Wiedeńskiego uważa angielskie poty za odmianę chorób zakaźnych - pochodnych grypy albo AIDS, eboli i SARS ${ }^{52}$. Badania prowadzono także w zakresie chorób układu oddechowego ${ }^{53}$, zwłaszcza wśród arbowirusów ${ }^{54}$. Pierwsi badacze natomiast rozważali zatrucie pokarmowe. Przyczyn poszukiwano zwłaszcza w wilgotnym klimacie wysp i w rozwoju grzybów ${ }^{55}$. Inni wskazywali na infekcje enterowirusem przenoszonym przez zanieczyszczoną fekaliami wodę ${ }^{56}$. Żadna z tych koncepcji jednak nie tłumaczy w pełni wszystkich opisywanych objawów ani błyskawicznego uśmiercania organizmu. Badacze zastanawiali się także nad faktem, dlaczego w szczególny sposób epidemia ta dotknęła mieszkańców wysp, zwłaszcza podczas pierwszej i ostatniej fali epidemii w 1551 r. Niektórzy świadkowie zwracali uwagę, że w $1517 \mathrm{r}$. choroba ta na terenie miast francuskich dotykała tylko kupców angielskich, w czym dopatrywano się szczególnych predyspozycji tej nacji do choroby ${ }^{57}$. Przyczyn szukano w ich sposobie odżywiania się, między innymi warzenia przez nich piwa ${ }^{58}$. Współcześni kronikarze, zwłaszcza z pierwszej połowy XVI w., szukali racjonalnych przyczyn błyskawicznego rozprzestrzeniania się choroby, rozważając ukształtowanie terenu (np. życie w dolinach rzek) albo intensywne kontakty handlowe prowadzone drogą morską.

Marcin Luter, który sam na nią zapadł, wypowiadał się na temat „chorujących” osób raczej lekceważąco, zwracając uwagę, że wielu ludzi przesadzało, bo gdy tylko zaczynali się pocić, kładli się do łóżka i czekali na śmierć. Stwierdzenia te świadczą o przerażeniu, jakie wywoływało w ludziach to doświadczenie ${ }^{59}$. Podobne zachowania zaobserwował cytowany powyżej Kantzow. W liście Lutra z 9 października 1529 r. do Wentzela, zaniepokojonego pojawieniem się epidemii ${ }^{60}$, reformator $\mathrm{w}$ ciekawy sposób tłumaczy psychologiczny wpływ, jaki choroba ta wywierała na współczesnych. Pisał o omamieniu, jakiego doznawali,

51 William P. Cheshire, Jay A. van Gerpen, James J. Sejvar, „Sudor Anglicus: an epidemic targeting the autonomic nervous system", Clinical Autonomic Research 30 (2020): 317-323.

52 Flamm, Anno 1529, 59-70.

53 Eric Bridson, „The English 'sweate' (Sudor Anglicus) and Hantavirus pulmonary syndrome”, British Journal of Biomedical Science 58/1 (2001): 1-6.

54 John A.H. Wylie, Leslie H. Collier, „The English sweating sickness (Sudor Anglicus): a reappraisal", Journal of the History of Medicine and Allied Sciences 36/4 (1981): 425-445.

55 Adam Patrick, "A consideration of the nature of the English sweating sickness”, Medical History 9 (1965): 272-279.

56 Paul R. Hunter, „The English Sweating Sickness, with Particular Reference to the 1551 Outbreak in Chester”, Reviews of Infectious Diseases 13/2 (1991): 305-306.

57 Hunter, „The English Sweating”, 304.

58 Püschel, „Der Englische Schweiß”, 162-163.

59 Wszak poprzednia fala epidemii miała miejsce w 1518 r., a od 1527 r. szerzyła się już w całej zachodniej części kontynentu.

60 „Denn ich habe in mancher Nacht geschwitzet, und bin vor Angst erwachet, und haben mich meine Gedancken auch angefangen zu plagen, und wenn ich ihnen hätte nachgehangen, so lage ich, wie andere, die da gelegen und sich selbst aufgeopfert haben”, cyt. za: Gruner, Scriptores de sudore, 433. 
które należałoby widzieć w kategorii śmiertelnego przerażenia paraliżującego logiczne myślenie. Podawał przykład swego znajomego, który uznał, że jest chory na angielskie poty: „Gdyby był to początek tej choroby, to musiałbym i ja [umrzeć - przyp. J.M.] w ciągu trzech lat, a często [na nią - przyp. J.M.] już chorowałem. Wtedy pociłem się przez wiele nocy, i budziłem się przerażony i także mnie zaczynały moje myśli dręczyć, a gdybym sobie je przypominał, także położyłbym się, jak inni, którzy tam leżą i się ofiarował [Bogu - przyp. J.M.]”. W dalszej części listu Luter wątpił w podawane do wiadomości liczby chorych. Winą za owo „zaślepienie” winił także rozpowszechniane publikacje na temat choroby. Zdaniem Lutra ludzie po ich przeczytaniu zaczynali każdy objaw potliwości przypisywać owej chorobie, gdy tymczasem setki osób w Magdeburgu zapadało na nią i nie umierało. Radził przyjacielowi, by jeśli zacznie się pocić, pozwolił organizmowi wypocić się, ile potrzeba, lecz nie dłużej, niż kondycja ciała tego wymaga. Inaczej, gdyby była to rzeczywista plaga, wówczas żadne lekarstwo nie pomoże ${ }^{61}$.

Dla miast pruskich dysponujemy szczegółową relacją postępów owej epidemii zapisaną w kronice Simona Grunaua. Dominikanin relacjonuje, że w Gdańsku nowa choroba pojawiła się 1 września 1529 r. ${ }^{62}$, a w Królewcu 5 września. Relacja Grunaua pozostaje badaczom szerzej nieznana. Nie notują jej ani literatura współczesna, ani obszerne wydanie wypisów źródłowych dotyczących epidemii potów angielskich zestawione przez niemieckiego historyka medycyny, rektora uniwersytetu w Jenie, Gottfrida Christiana Grunera (1744-1815) ${ }^{63}$. Zbiór ten liczy ponad 500 stron i sam w sobie pokazuje, jak wielkie zainteresowanie wywołała nowa choroba wśród współczesnych w trakcie każdego z pięciu nawrotów choroby. Grunau pozostawił nam nader interesujące świadectwo, ponieważ był naocznym świadkiem plagi. Jeśli pominiemy interpretacje teologiczne kronikarza, to jego dzieło jest najbardziej obszernym i szczegółowym źródłem dla miast pruskich ${ }^{64}$.

Epidemie - pisał kronikarz - dotykały zazwyczaj słabych i niedożywionych ludzi z dolnych warstw społecznych. Tymczasem angielskie poty rozprzestrzeniały się wśród dobrze urodzonych i sytuowanych ludzi, żyjących w dobrych warunkach bytowych ${ }^{65}$. Choroba ścinała ludzi z nóg i to dosłownie. Kto rankiem

61 Ibidem, 434.

${ }^{62}$ Zgodnie odnotowują tę datę także inne gdańskie kroniki z połowy XVI w., zob. załączniki źródłowe.

63 Gruner, Scriptores de sudore.

64 Zestawienie epidemii w Gdańsku podaje Edmund Kizik, nie uwzględnia ono jednak relacji Simona Grunaua: Edmund Kizik, „Zarazy w Gdańsku od XIV do połowy XVIII wieku. Epidemie oraz liczba ofiar w świetle przekazów nowożytnych oraz badaczy współczesnych", w Dżuma, ospa, cholera. W trzechsetna rocznice wielkiej epidemii w Gdańsku i na ziemiach Rzeczypospolitej w latach 1708-1711, red. idem (Gdańsk: Muzeum Historyczne Miasta Gdańska, 2012), 64, 70.

65 Grunau, Bd. 3, 273. 
wstał zdrowy, w południe leżał z gorączką, a wieczorem był martwy. Wirus zabijał w 24 godziny każdego, bez względu na płeć, wiek i stan zdrowia. Grunau pisze: od św. Idziego (czyli 1 września) ludzie umierali z dnia na dzień setkami i tysiącami, a zaczynało się od gorączki - u jednych trwała ona sześć godzin, u innych 12, 18, lecz maksymalnie 24 godziny. Ten, kto pozostał w cieple i pocił się obficie, przeżywał, kto jednak tego nie zrobił, umierał. Sprawdzona rada była następująca - kto zachorował w jakimś ubraniu, także w nim musiał się wypocić, głowa, stopy, dłonie, całe ciało musiało nie mieć dostępu do powietrza. Jeśli wypił zimną wodę albo wystawił stopę lub dłoń, by się ochłodzić, nawet na długość trwania Ave Maria lub tylko na trzy Ojcze nasz, i nie został szczelnie okryty skórami, ten niechybnie umierał. Nikt nie był bezpieczny i nie mógł być pewny jutra - pisał Grunau. Epidemia trwała przez całą jesień. Niewielu było ludzi w kraju, którzy nie zachorowali, z wyjątkiem dzieci. W samym Gdańsku zmarło, jak podaje kronikarz, 2500 („drittehalb”) osób (ogólna liczba mieszkańców Gdańska wówczas wynosiła ok. 40 tys.). Plaga rozprzestrzeniała się wśród najzamożniejszych i najlepiej sytuowanych ludzi - rajców, junkrów, kupców, mężczyzn i kobiet. Nie byli oni ani słabi i biedni, ani starzy, lecz w kwiecie wieku i pełni zdrowia - pisał kronikarz ${ }^{66}$. Podawana przez kronikarzy liczba ofiar jest trudna do zweryfikowania, inni gdańscy kronikarze podają liczby między 200 a 1500 ofiar. Autor Kroniki Pelplińskiej szacuje łączną liczbę ofiar w Królewcu i Gdańsku na około $3300^{67}$.

Martwe ciała zalegały na ulicach Gdańska, nikt nie chciał ich tknąć i pochować, mimo że za pochówek oferowano aż 10 grzywien! Wkrótce rajcy miejscy najęli kilku Polaków i Litwinów, którzy pozbierali ciała i pogrzebali je - relacjonuje dalej Grunau. Przerażeni mieszkańcy Gdańska zaczęli uciekać poza miasto i szukać ratunku gdzie indziej - udawali się do Oliwy, Pelplina ${ }^{68}$, Sartowic, Żukowa, Kartuz i okolicznych wsi, które zaludniły się błyskawicznie. Po trzech dniach choroba rozwinęła się w epidemię i zajęła całe Prusy. Najbardziej dotknąć miała Gdańsk i Królewiec, co zapisali mnisi pelplińscy, szacując łączną liczbę ofiar w tych miastach na około 3 tys. ${ }^{69} \mathrm{~W}$ ten sposób po ośmiu dniach zawleczono chorobę do Elbląga. Tam, jak podaje Grunau, zmarło znacznie mniej osób - tylko $43^{70}$. Gdańszczanie uciekali także do Torunia i Królewca. Początkowo torunianie nic nie wiedzieli o pladze, a że prowadzili liczne interesy z gdańszczanami, przyjęli kupców jak zwykle. Torunianie przerazili się, gdy zdrowi jeszcze rankiem kupcy następnego dnia już nie żyli. Mieszkańcy miasta zaczęli uciekać na wieś, a ci, którzy musieli zostać, wypędzili gdańszczan z miasta, musieli oni z małymi dziećmi jak cyganie koczować na polach. Grunau podaje, że plaga zabrała

\footnotetext{
66 Grunau, Bd. 3, 273.

67 Kronika Pelplińska, 173-174; zob. załączniki źródłowe.

68 O epidemii tej informuje Kronika Pelplińska (ok. 1588 r., w kopii z XVII w.); zob. załączniki

69 Kronika Pelplińska, 173-174; zob. załączniki źródłowe.

70 Grunau, Bd. 3, 274.
} źródłowe. 
setki znamienitych osobistości Torunia ${ }^{71}$. Miasto zamknęło bramy, a wypędzeni i uciekinierzy z miasta musieli przebyć dwutygodniową kwarantannę, ażeby dowieść, że nie są zatruci. Kto był nadal zdrowy, wpuszczany był do miasta, kto chorował, nie miał wstępu ${ }^{72}$, co w praktyce skazywało go na śmierć.

Gdańszczanie zawlekli chorobę również do Królewca, gdzie wybuchła ona 5 września. W tym czasie książę Albrecht organizował zjazd w Królewcu, na który przybyli znamienici goście, także z Gdańska, a wraz z nimi łodzie z uciekającymi przed epidemią mieszkańcami tego miasta. Już w nocy wirus uśmiercił 18 gdańszczan, a kolejnych 21 zmarło w drodze na łodziach. Grunau opisuje sytuację, kiedy to jeden z gości, przemawiający na zjeździe przed księciem, nagle padł martwy, a po nim jeszcze dwóch innych. Następnego dnia na marach leżało już 60 osób, które rano były jeszcze zdrowe. Ludzie zaczęli w przerażeniu uciekać ze zjazdu, by jak najszybciej opuścić miasto, lecz śmierć zabierała ich po drodze, na przykład biskupa Gerarda von Queissa (zm. 10 września) ${ }^{73}$. Sam książę także zachorował i wyjechał do Fischhausen, by się kurować. Chorowała także jego żona i dzieci, kapłan Paul Speratus z małżonką, o czym informuje Albrecht w swym liście z 13 września do brata Georga von Brandenburga ${ }^{74}$. Po wypoceniu się książę pokonał chorobę. Epidemia w Królewcu miała wystawić na próbę wiarę luterańską, jak pisze dominikanin, który nie omieszkał wytknąć księciu Albrechtowi, którego szczerze nienawidził, że zmożony chorobą przywrócił na krótko katolickie obrządki - procesje, bicie w dzwony i śpiewy, by zaraz po wyzdrowieniu wrócić do herezji. Zdaniem gdańskiego kronikarza plaga ta, tak niezwykła, bo błyskawiczna, była karą za sprzyjanie luterańskim naukom obrażającym Boga i świętych ${ }^{75}$. Także w Królewcu miano wydrukować jeden z traktatów informujących, jak radzić sobie z nową epidemią. Informuje o tym notatka, którą biskup warmiński Maurycy Ferber zapisał w załączniku do listu skierowanego do księcia Albrechta 15 września (tj. w czasie choroby księcia) ${ }^{76}$. Zapisał w nim, że zakupił w Królewcu druk poświęcony angielskim potom i zwraca uwagę, że zawarte w nim porady uleczyły już wielu ludzi. Niestety, nie jest jasne, czy poradnik ów został w 1529 r. wydrukowany w tym mieście. Jeśli tak było, to nie zachował się ani jeden egzemplarz druku królewieckiego wydanego w tym roku.

${ }^{71}$ Nie zachowały się współczesne relacje kronikarskie $\mathrm{z}$ tego miasta odnoszące się do epidemii z 1529 r. Przyczyną może być słaby stan zachowania bazy źródłowej z początku XVI w. W zachowanym toruńskim materiale kronikarskim z późniejszych okresów także brak takich informacji.

Grunau, Bd. 3, 273.

73 Zob. także Johannes Freiberg, „Die Chronik des Johannes Freiberg”, w Scriptores rerum Prussicarum. Die Geschichtsquellen der preussischen Vorzeit, Bd. 6, bearb. v. Udo Arnold (Frankfurt am Main: Minerva GmbH, 1968), 498.

${ }^{74}$ Urkundenbuch zur Reformationsgeschichte des Herzogthums Preußen, hrsg. v. Paul Tschackert, Bd. 2: Urkunden, Th. 1: 1523 bis 1541 (Leipzig: Verlag von S. Hirzel, 1890), 222, nr 655.

75 Grunau, Bd. 3, 278.

76 Geheimes Staatsarchiv Preußischer Kulturbesitz Berlin (dalej: GStA PK), XX HA HBA C 1. Nr 166, zob. załączniki źródłowe. 
Biskup nie podaje ani drukarni, ani autora pracy. Poszukiwania w zachowanej kolekcji książek księcia Albrechta nie przyniosły pomyślnych rezultatów ${ }^{77}$. Drukarnia Hansa Weinreicha już w 1527 r. wydała traktat poświęcony zwalczaniu epidemii ${ }^{78}$, nie można zatem wykluczyć, że w 1529 r. powieliła jeden z licznych traktatów dotyczących angielskich potów drukowanych w Europie lub wydała jakiegoś rodzaju druk ulotny na ten temat.

Podsumowując, w świetle powyższych analiz relacje Simona Grunaua na temat epidemii z lat 1527 i 1529 uznać należy za wysokowartościowy i wiarygodny przekaz naocznego świadka. Krok po kroku ukazał rozpad znanego na co dzień porządku społecznego w wielkich miastach. Bezpieczne dotąd życie w obrębie murów miejskich stało się, zwłaszcza w obliczu tajemniczej epidemii angielskich potów 1529 r., przekleństwem - ludzie upatrywali ratunku w opuszczeniu miasta. Dumni posiadacze nieruchomości i statków zostali postawieni w sytuacji bezdomnych koczowników, takich jak cyganie - symbolizujący antytezę miejskości i cywilizowanego życia. Konfrontacja relacji kronikarskich $\mathrm{z}$ materiałem epistolarnym pokazuje różnorodne reakcje ludzkie na pojawienie się nowej, nieznanej epidemii - strach, zwątpienie, posądzanie o lęk przed karą bożą za grzeszne życie, narażanie na śmieszność z powodu przesadnych reakcji obronnych - te ludzkie słabości (sądzących i posądzanych) pozostały niezmienne do dziś.

\section{Załączniki źródłowe}

\section{ROK 1527}

\section{Simon Grunau, Preussische Chronik ${ }^{79}$}

(s. 228)

$\$ 131$. Wie geschwiere und frantzosen im viehe gefunden wardtt, das man essen solte.

In dem herbestt dieses jahres starb in Preusen viell folk, nichtt das es ein gemeine pestilentz war, dennoch, welche krank wurden, denen war nichtt zu helfen. Sonderlich wardtt die krankheitt, die frantzosen genanntt, sehr gemein und

77 O tym, że książę Albrecht posiadał w swojej prywatnej Kammerbibliothek traktaty medyczne, a także te poświęcone epidemiom, świadczy zachowany katalog, Peter G. Thielen, „Ein Katalog der Kammerbibliothek Herzog Albrechts von Preussen aus dem Jahre 1576", Jahrbuch der Albertus-Universität zu Königsberg 4 (1954): 222.

78 In diesem buchleyn findestu die allerschönste Regyrung ynn der pestilencia vnd ist offte vnnd übermasse viel vorsucht vnd manichmol bewert [Königsberg: Hans Weinreich, ca. 1527], $8^{\circ}$ (VD 16 A 1922); Paul Schwenke, Hans Weinreich und die Anfänge des Buchdrucks in Königsberg (Königsberg: Verlag von Ferd. Beyer's Buchhandlung, 1896), 46, nr 40.

79 Grunau, Bd. 3, 228-229. 
war giftiger, den vormals, das auch, wen die, so damitt behaftt, geschmierett wurden auf die weise, wie vorhin, so funden sie nichtt besserung, sondern wurden viell mehr gepeinigett, das also die frantzosenartzte nichtt wusten, wie thun, sintemahll den auch viell der kranken arm waren und sich mitt arbeitt ernehren musten. Wen aber die gesunden ihre geschwere sahen, erschracken sie davor und befunden an sich, das sie die seuche durch das erschrecken oder entsetzen auch bekomen. An welchen man aber die krankeitt nichtt sahe, die hielten sich bei den leuten gemein und ihrer viell damitt vorgiften.

Als die plage sehr gemein war, alle artzenei, die vorhin geholfen, auf die zeitt schedlich, und man nichtt wuste, woher es keme, nachdem aber nach Micheli ein jeder sein viehe, als ochsen, schweine, und der gleichen in seine haushaltung schlachtete, da wurden fastt an allem viehe solche blottern gefunden, wie die frantzosen an den menschen waren. //

(s. 229) Das kam vor den rahtt. Der bepfulI, alles fleisch wegkzuwerfen, sondern viell aus armutt es vorbergeten und assen. Dem einen bekam es bass, den dem andern. In dem wardtt es auch offenbar, das die fleischauer das gantze jahr durch solch fleisch vorkauftt. Als man sie strafen wolte, sprachen sie, sie hetten es vormals nichtt erkantt, fortan aber wurden sie strafe gnug haben, sintdem sich ein jeder vor dem fleische scheuen wurde. Es wardtt auch nach diesem wenig fleisch gekauftt; wo man es je gekauftt, so wardtt es gar woll beschauett und durchschnitten, dadurch das handttwerk der fleischauer in grose armutt kam. Da sprachen sie: dies vor jenes; in der zeitt der lutterei wir in allen fasttund fleischtagen alle zeitt gleich fleisch vorkauften, itzundtt aber wirdtt unser fleischfressen durch die frantzosen besuchtt.

Mitt der milchspeise hette es auch keine gestaldtt, noch geschmack, wievormals; ihrer viell sich da vorentsatzten, gebrauchten der Schwedischen und Hollandischen milchspeise, den sie vormeinten, alles viehe in Preusen were mitt den blottern der frantzosen vorgiftett. So war es auch wunderlichen anzusehen, das, wen die huner, so woll im hause, als auf der gassen gehende, sich bospeiseten, kam es ihn an, das sie bei dreissig mahlen ins runde umbher liefen, endlich sturtzten und blieben todtt, das auch alle mistthaufen foll lagen. Der von zehen hunern eines bohieltt, das war ein gluck. Solches war in gantz Preusen gar gemein, dennoch an einem ortt mehr, als an dem andern. Wen ferkell, huner, gense, enten und dergleichen abgethan wurden, fandtt man blottern darin. Dieweill es dennoch muss gegessen sein, so schnitt man die blottern aus und kochte das ander in gottes namen und sprachen: da wir nichtt solten fleisch essen, assen wir es aus frewell; billig wir itzundtt am fleisch die krankheitt und den todtt fressen; wen es nur damitt vorrichtt were, das unser vollbruttigkeit aufhorte! etc. 


\section{ROK 1529}

Załącznik do listu bpa warmińskiego Maurycego Ferbera do księcia pruskiego Albrechta $z 15$ września 1529 r. (Lidzbark Warmiński)

GStA PK, XX HA HBA C 1, Nr. $166^{80}$

Wie sich der mensch disser krankeyt halten soll, ist im druck ausgangen und in e[uer] f[urstlichen] d[urchlauch]t stat Konigsperg verkaufft wurden. So haben wir dan von unnser freuntschafft, welche eyns teils sampt andern myt disser plagen befallen und gewehsen seÿn, dissen in geschlaffenen proceß auch uberkommen, denen wir e[uer] f[urstlichen] d [urchlauch]t freuntlicher meyhnung zcu gut und besten mytzcutheÿlen, nicht haben wollen undterlassen, dan er seint alhie auch ettliche menschen damyt errethtet, der almechtig thu uns alle errethten. Dat[um] ut $\sup [\mathrm{ra}]$.

\section{Simon Grunau, Preussische Chronik ${ }^{81}$}

(s. 272)

$\$ 165$. Von einem schnellen todtt.

Als die blase auf dem daunesten war, besuchte gott die Preusen also, und zum ersten Dantzick. Die prediger zu Dantzick, so von koniglicher ma. vorordenett, vornahmen nach der heiligen schrifftt, das gott die sunde, schande und laster, welche in Preusen gar gemein war, nichtt wurde ungestrafett lassen. Derhalben baten und vormaneten sie das folk, sie solten abelassen und busse thun; aber sie wurden darumb gelestertt, gefluchtt, vorspottett und belachtt und sprachen: den heuchlern gehett der fette bauch abe, derhalben bedrauen sie uns mitt der strafe gottes und meinen, gott sei so ein wuterich, wie sie samptt unserm konige sein. Nach dem geschahe //

\section{(s. 273)}

es also: am tage Egidii [ 1 IX] hette man nichtt gehortt, das in Dantzick jemands krank were, auf die folgende nachtt und den halben tagk darnach wurden todtt gefunden drittehalb hundertt personen, und das von den namhaftigsten, als rahttheren, junkern, die ihre landttgutter hetten, kaufleute, mahn und frauen. Als solches auf den mittagk offenbar wardtt, erschracken die andern, sie spinnen an, wolten wegk und sich anderswo retten. Im anspannen, im auftragen, im register schreiben, im zur stadtt ausfahren sturben sie. Das machte da erstlich eine furchtt, das die burger und gesinde, hauss und hof vorliefen und wusten doch nichtt worhin, und werete solch jamer und nohtt drei tage und zwei nachte. So war auch niemandtt, der die todten begrub, wiewoll man vor etzliche zehen mark bott. Die todten lagen so lang auf der gassen, biss der rahtt etzliche Polen und Littauen

80 Zob. także Stefan Hartman, Herzog Albrecht von Preussen und das Bistum Ermland: Regesten aus dem Herzoglichen Briefarchiv und den ostpreussischen Folianten (Köln: Böhlau, 1991), 99.

${ }^{81}$ Grunau, Bd. 3, 272-278. 
von den weisellkahnen zwang, die todten aufzulesen und zu begraben. Es waren insgemeine nichtt arme, sondern die reichsten, vornehmsten und namhafsten, nichtt junge, noch alte, sondern personen die in ihren besten tagen waren, und waren ihrer tausentt borechnett, die so plutzlich sturben. So kamen dennoch viell gesunde aus der stadtt wegk; derer waren die kloster Oliva, Pelplin, Zarnowitz, Suekau, die Carthaus und alle dorfer umb Dantzick foll, die sturben nach einander ohn unterlass wegk, dadurch die andern vorzageten. Man wolte keinen in die stadtt lassen fuhren und begraben, auch nichtt lassen leuten, das so allentthalben schrecken war des schnellen todes. Nach dreien tagen wardtt die schnelligkeitt vorwandeltt in ein febris pestilentialis und kam ins gantze landtt Preusen; es kam den leuten mitt der hitzean, etzliche sechs stunden, etzliche zwelf stunden, etzliche achttzehen stunden, etzliche vierundzwenzig stunden, etzliche und das gemeineste zu dreissig stunden ohn unterlass schwitzten; welche sich den warm hielten und schwitzten, die kamen wiederumb auf, welche aber nichtt, die sturben. Es war so eine weise: in welchem kleide sie krank wurden, darin musten sie auch ausschwitzen, hauptt, fusse, hende, samptt dem gantzen leibe muste keine luftt haben. Wo jemands einen andern trunk thett, den ochsenzungenwasser, oder dem zugegen, das von natur kaldtt istt, oder ein handtt oder fuss nur ein ave Maria lang kulete, oder drei vaterunser lang schlief, oder mitt federbetten bedecktt wardtt, der starb im nu wegk, das es fastt niemandtt gewahrwardtt. Es waren wenig im lande, die das schwitzen nichtt hetten, ausgenomen die kinder, und werete so //

(s. 274)

hin und her in einer stellen mehr, den in der andern, den gantzen herbstt durch.

$\$ 166$. Wie dieselbige pflage gen Elbing kam.

Als die pflage zu Dantzick achtt tage lang gedaurett, kam sie auch gen Elbing, aber wehrlich gar gnedig, den es sturben nur drei und vierzig personen, und das von ihrem eigenen vorwarlosen.

$\$ 167$. Wie diese krankheitt gen Thorn kam.

Viell der Dantzker kaufleute, die vor dem sterben aus der stadtt gewichen waren, kamen mitt den ihrigen gen Thorn. Dieweill den die Thorner der Dantzker vorkaufer sein, den sie mitt ihrem gelde handeln, nahmen sie die Dantzker auf, sie wusten aber nichtt von der schnellen plage. Auf die folgende nachtt sturben da etzliche der Dantzker, auch viell der Thorner, die gesundtt waren schlafen gangen. Auf den morgen machten sich die Thorner auf und vorliefen ihre stadtt. Das teill, welches bleiben muste, trieben die Dantzker, ihre geste, aus, die musten sich mitt ihren kleinen kindern auf dem felde, wie die zieganen, bohelfen, und ihrer viell sturben daselbstt von muhe und wiederwillen. In der stadtt Thorn es auch rumorte und nahm in die hundertt namhafte personen wegk; sie giengen gemeinlich mit bluten dahin, sonstt lag fastt die gantze burgerschaftt, sie kamen aber auf. Ihre burger, die vor dem tode gelaufen waren, derer liessen sie keinen 
ein, es war gleichs burgemeister, rahtther, scheppe, hoch oder nieder gesessen, ehr muste den zuvor vierzehen tage vor der stadtt auf den garten gelegen haben umb erfahrung willen, ob ehr auch vorgiftt were. Blieb er indem gesundtt, so liess man ihn ein; war aber jemands krank, der muste in die stadtt nichtt komen. Und alle, die in dieser pflage vorgiengen, so woll zu Dantzick, als zum Elbinge und Thorn, auch anderswo, das waren alle treffentliche lutteraner.

\section{(s. 275)}

$\$ 168$. Wie die pflage gen Konigsberg kam und grosen schaden thett.

Den sontagk nach Egidii [5 IX] in diesem jahr under dieser pflage hette Albertus, der furstt, zu Konigsberg vorsamlett seine bischofe, adell und alle seine stedte, hielte mitt ihnen eine tagefahrtt. Auf das aber alle ding vom gottlichen worte ein schein hette, gieng der furstt mitt seiner landschaftt in die kirche, die predige zu horen, aber auf fromen des fursten. Daselbstt wardtt abgekundigett: sintemahll ein speter augstt were, bepfule der furstt mitt seinen prelaten, man solte keinen sontagk feiren, sondern vor und vor nach lustt arbeiten.

Es weren furstlicher erlauchtigkeitt briefe komen, wie zu Dantzick das dritte teill der menschen in tagk und nachtt vorgangen were durch den schnellen todtt, und were billig uber sie, den sie weren umb des koniges willen von dem lutterischen evangelio gefallen. Derhalben solten sie gott und ihrem fursten danken, der sie bei dem rechten evangelio hielte, und weren also pflage frei, die andern musten leiden. [...]

\section{(s. 276)}

[...] In dem selben sontage spete am abende kamen weisellkahne, schmacken und bote foll mitt Dantzker burgern, welche die stadtt Dantzick umb des sterbens halben vorlaufen hetten, die wurden von ihren bekanten mitt allem hone entpfangen sprechende: ihr Romischen cristen, komtt ihr nu zu uns lutterischen ketzern? wor istt nu euer antecristt, der bapstt, mitt seinem ablass und putterbriefen? wor istt nu sein heuchler, der konigk von Polen, mitt seinen getherten und geschmerten spitzhuten, die euch vorboten haben, dem lautern worte gottes zu folgen? Selig seidtt ihr, die ihr noch in nothen zu uns komtt, den gott istt mitt uns; sintdem wir dem Lutter folgen, sein wir sicher aller pflage, die ihr geschmecktt. Auf solches gebrachen den Dantzkern cristliche worte, und sie fielen der ketzerei Lutteri wieder zu.

Auf die nachtt blieben von den Dantzker nachtt zehen personen todtt, die man mitt den ein und zwenzig personen, welche under wegen auf den schiffen gestorben in eine grube legte, und wardtt uber sie weder Lutters, noch Cristus wortt gesungen. Es waren alle summa keufers, die durch Konigsberg in Littauen, Moscau und Samaiten handelten. Ehe solches gar offenbar wardtt, furchte sich ein ider vor dem fursten umb herbergung halben der Dantzker; sie stilleten es, wie sie beste kunten.

Der furstt kam indem mitt seinem adell und landschaftt zusamen. Sie gaben ihm auf die gepredigte artikell seines antragens durch einen ritter antwortt, solches nichtt zu thuende. Als ehr an dem besten redete, sturtzte ehr dahin und blieb 
todtt, von welchem sie alle erschracken. Indem sturtzte noch ein edellman und blieb todtt, uber ein kleines noch ein ander.

Da wardtt dem fursten gesagett, ehr solte sich wegk machen, den man hette den morgen sechszig personen gesehen danieder sturtzen und todtt geblieben, welche des morgens weren gesundtt gewesen. Auf solches riss der adell und die landschaftt von einander, gleichs wen man unter einen haufen wolte scheustt; aber ihrer viell kamen //

\section{(s. 277)}

nichtt lebendig heim, sondern sturben auf dem wege, wie auch Gerardus, der nam- und ketzerbischof von Marienwerder, so auch eilf edelleute hin und her auf der strasen in dem abscheide von Konigsberg sturben.

Als der furstt wolte auf sein ross sitzen, sturtzte der, welcher es ihm hieltt, danieder und starb, davon der furstt sehr erschrack und wardtt gleichs wie sinneloss, springett in dem auf sein pferdtt, reitt in einem jagen auf Fischausen zu; da ehr zu seinem weibe kam, legte man ihn vor todtt ins bette. Desselben tages wardtt die furstinne von einem reutenden boten underrichtt, welcher von Dantzick uber die Nerung dahin kam, von der neuen pflage und ihres regiments; derbalben hielte sie mitt ihren jungfrauen den fursten warm. Als ehr achttzehen stunden gelegen, vorzagte ehr an seinem leben, da lies sehr ein brief schreiben, sich beklagende aller uncristlichen sachen, die ehr mitt seinem folk geubett hette, sonderlich da sehr sie vom rechten glauben hette lassen vorfuhren etc., derhalben bete ehr gnade und vorzeihung von ihnen. Auch schrieb ehr an die Konigsberger, sie wolten processiones zu den kirchen anstellen, psalme singen und alle glocken lauten, ob ihm gott sein leben fristen wolte. Solches theten sie mitt fleiss welche daselbstt noch gutte cristen waren, wusten woll, das man nichtt solte boses mitt bosem rechen. Sintemahll den vorlaufenen munchen viell an dem fursten gelegen war, lautt man alle glocken mitt machtt. Nu siehe, was dies istt: vor diesem zurbrach und vorschmeltzte man die glocken als ein ding der abgotterei und lesterung gottes und nanten das glocken lauten und beiern des teufels orgeln; itzundtt aber in nothen wurden sie umb der gesundheitt aller gelautt. Die vier und zwenzig stunden kamen mitt der krankheitt und ihrer artt umb, da wardtt der furstt rasende: alle weldtt an ihm vorzagte und sagten ihn todtt, den niemandtt ihm das leben

vortrauete. Solche geschrei kam balde gen Konigsberg und auch //

(s. 278)

weiter, wieder furstt todtt were, welches machte freude und botrubnis. Aber gott es in seinen heimlichen gerichten wandelte: als der furstt dreissig stunden an dem schwitzen hette gelegen, kam ehr zu ihm selbestt; ehr sagte und bekante mitt weinen seine schuldtt und dankte gott vor die strafe.

Im ersten tage, als die Konigsberger die pflage vormerkten und sahen, das der adell also ausriss, vorliefen sie auch ihre stadtt, das nur ein burgemeister blieb, welcher die gichtt hette, sie erfulleten alle umbliegende dorfer, aber sie sturben 
daselbstt wegk ungezeltt. Inwendig vierzehen tagen sturben in der stadtt und sonstwor die burger von Konigsberg samptt ihren gestenden Dantzkern, die umb des lebens willen zu ihn geflohen waren, eilf hundertt und vierundzwenzig personen, welche alle namhaftig und auf ihrem besten waren [...]".

Tak zwana Kronika Kattenhöfera (poł. XVI w.)

APG, Rękopisy elbląskie, 492/659, fol. 107r (ołówkowa, s. 213)

Den j [1.] im September, do hub sich an eine Neüe kranckheitt zur Danczke, die schweis kranckheit genenet, die zuvorn nie gehorett war und die sie krigten, die musten 24 stunden ligen, das sie nich kalt worden, oder sie sterben, und die daran lagen, das waren Leüte auff irem besten, keine alde leuth oder kinder, das wart mit inen besser in 24 stunden, oder sie waren Todt, dieses werett drë̈ tagk langk, das dar uber 200 Personen sterben und vil aus dem Rath, das war seer erschrecklichen.

Kronika Bartolomäusa Wartzmanna (tzw. szeroka)

BG PAN, Ms 1285, k. 391v (spisana między 1545 a 1558 r.)

Dye schweyseuche ist ein sunderliche sterbliche plage gottes unsers herr[n] gewesenn, hat sich in disem jare angefangen tage Egidie [ 1 IX] auf eyne[r] entworf, weret nur in denn dritt[en] tagk und sinndt uber 300 mensch gestorbe[n], gott sei inne[n] gnedich und barmhertzick.

\section{Kronika Georga Melmanna}

APG, 300, R/Ll, 1, s. 970-971 (tzw. duży Melmann), z 1548 r., w kopii z XVII w.

In diesem Jahre war ein groß sterben zu Dantzig, an der // Schweiß Kranckheit, also daß in kurtzen tagen bey 1500 menschen gestorben sind.

Kronika zakonna anonimowa, spisana w Gdańsku

AP Gdańsk, 300, R/Ll, 9, s. 578, połowa XVI w.

Anno 1529 umb die zeit Egidij [1 IX] wartt zum erdten die schweiß krankheit gespuckt, darann viel volck starb welchs zum teil erstickten, und erdicsten dran die leute wurden zwischen dran betten vernehet damit kein lufft an sie konnen solt. Es war aber eine besondere plage und straffe gottes etc.

Kronika Johannesa von Freiberga ${ }^{82}$ (poł. XVI w.)

In selben Jare vngeuerlich um Michaelis [29 IX] auß kam eine krangkeit hieher In preußen, genant die Schweißkrangkheit. Die leute lagen nun 24 stunden, welche die 24 stunden nicht vbirstreben unten, sturben, den die leute wusten In der ersten nich wie man sich In diser krangheit halten solde, das auch vil volcks mit den ersten zu Danczig vnd alhie sturben.

82 Die Chronik des Johannes Freiberg, 498. 
Vmb dieselbige Zeit wart eine Tagefart alhie gahalten zu kongspergk, ich gedenke der Muncze halbenn, v. g. h. zugk von hie vnd befole den andern herrn nicht voneinander zuziehen, biß zu ende were gebracht der tag. Aber die angst kam Inen so hart ahn, das sie von einander zogen ehe das etwas kunt gehandelt werden vff dem Tage. Der Bischoff von Risenburg Ehardus Qweicz wart vnderwegen krangk vnd starb vff der heimereyse. Der Canczler Doctor vischer starb auch das mal etc. Vnd got besuchte vnsern Fursten auch mit der Newen krangkheit, do war ein solch bitten vor In von den predigstulen das In got solt fristen, er wolde sich bokern vnd beßernn seinen armen vnterthanen wol vorsehen etc. vnd ließ die kethenerß vnd andere gefangene loß geben.

Kronika Pelplińska ${ }^{83}$ (z ok. 1588 r., w kopii z XVII w.) Archiwum Diecezjalne w Pelplinie, Chronica Monasterii Sacri Ordinis Cisterciensium Pelplin, cz. 1, codex 421 (622), 173-174

Eodem anno Inauditus et contagiosus morbus in Autumno hic in Prussia grassari co[e]pit communiter Anglicanum wel vulgo Schweißkranckheit appellabant, affectu[s] hiems ultra 24 horas non tolerabat. Hic morbus maxime Gedani et Regiomonti et circa adiacentia loca serpebat dicunt[ur] hac 30 ultra 30000 summa interijste.

\section{Julia Możdżeń}

\section{Syphilis, smallpox, English sweats. Forgotten epidemics in Prussia and Pomerania in 1527 and 1529}

This article aims to analyze narrative material recorded in Prussian and Pommeranian towns in the course of an epidemic of syphilis and smallpox in 1527 and of English sweats in 1529 (chroniclers' accounts and letters). The point of departure is the extensive and detailed description contained in the Preußische Chronik by the Gdańsk chronicler Simon Grunau. To test its credibility, the information it contains is compared with other current accounts on the subject of the course of the epidemics. Hitherto the epidemics of 1527 and 1529 have not aroused the interest of scholars writing about Prussia and Pomerania. The author of this article has collected manuscripts and printed source material, which is included in an annex. The article analyzes: the reactions to the appearance of sickness on the part of city authorities noted by chroniclers (including, Simon Grunau, Thomas Kantzow, and Johannes von Freiberg) and of the inhabitants of Szczecin, Gdańsk, Königsberg, Torun, and Elbląg; descriptions of the remedial measures proposed; and interpretations of the ways the sicknesses spread among people and domestic animals. The article compares these with accounts surviving in contemporary letters, including those of Martin Luther, Prussian Duke Albrecht Hohenzollern, and Philip Melanchthon; it also considers accounts

83 Kronika Pelplińska, 173-174. 
from the extensive medical writing preserved in old printed texts. An analysis of the epidemic of 1527 makes it possible to identify several diseases (smallpox and bird flu) that chroniclers identify with syphilis. The surviving accounts of witnesses point to convergent reactions of people to new illnesses with those observed today. 